\title{
RANCANG BANGUN WEBSITE TOKO ONLINE MENGGUNAKAN METODE WATERFALL
}

\author{
Muhammad Susilo $^{1}$, Rezki Kurniati ${ }^{2}$, Kasmawi ${ }^{3}$ \\ ${ }^{1}$ Politeknik Negeri Bengkals, Indonesia \\ Jln. Bathin Alam, Sungai Alam, 28712, Indonesia \\ Siloms12@gmail.com,Rezki@polbeng.ac.id, Kasmawi@polbeng.ac.id
}

\begin{abstract}
Abstrak-Website Toko online dapat memudahkan pelaku usaha atau toko untuk mempromosikan produknya dan mempermudah konsumen untuk mendapatkan informasi tentang produk-produk yang dimiliki penjual atau toko. Keterbatasan Pemasaran produk menjadi suatu kendala toko dalam meningkatkan omset penjualan toko dan lemahnya pengawasan barang serta pembuatan laporan yang masih manual menjadi suatu dampak yang buruk bagi toko sehingga laporan penjualan dan laporan stok barang menjadi terhambat. Tujuan dari penelitian ini adalah membuat website toko online menggunakan metode waterfall yang dapat diakses secara online. Metode yang digunakan peneliti untuk penelitian ini adalah metode waterfall. Metode ini digunakan peneliti untuk mengembangkan sistem-sistem perangkat lunak dengan memiliki alur hidup perangkat lunak secara terurut yang dimulai dari analisa, desain, pengodean dan pengujian. Perancangan sistem menggunakan Unified Modelling Language, Bahasa pemograman PHP dan database MySQL. Penelitian ini menghasilkan aplikasi Toko online berbasis web yang memberikan informasi stok secara real-time, Laporan penjualan, laporan stok barang, dan toko dapat mempromosikan produk yang dijual. Sehingga proses pelaporan dan pengontrolan informasi secara stok barang dapat dilakukan dengan baik serta jangkauan pemasaran toko dapat lebih luas sehingga dapat meningkatkan omset penjualan toko.
\end{abstract}

Keywords - MySQL, Toko Online, Website, PHP.

\section{PENDAHULUAN}

Sistem penjualan dan promosi produk melalui internet sedang berkembang pesat. Perusahaan yang memanfaatkan teknologi berbasis web sebagai suatu strategi perusahaan dalam menawarkan produk kepada seluruh konsumen tanpa harus dibatasi oleh ruang dan waktu. Mulai dari perusahaan besar hingga usaha kecil dan menengah telah menjadikan sistem penjualan secara online sebagai sarana promosi yang murah dan terjangkau [3].

Daerah Bengkalis terdapat beberapa Toko yang menjual aksesoris komputer dan laptop. Toko-toko memerlukan perluasan dalam bisnis penjualan produk-produk yang disediakan oleh masing-masing toko. Toko-toko aksesoris komputer di bengkalis masih bersifat konvensional (Offline) dimana jika Konsumen ingin melakukan pembelian atau hanya sekedar melihat produk masih harus dating langsung ke toko. dengan datang langsung ke toko tentu saja membutuhkan waktu yang cukup lama. Konsumen juga kesulitan untuk mendapatkan informasi tentang berbagai produk dan merek yang dijual oleh toko karena pemasaran produk hanya dipasarkan di toko. toko juga harus membangun stand di depan toko ketika toko akan promo produk.

Untuk memecahkan permasalahan tersebut. Mendorong penulis untuk membangun website penjualan secara online untuk memperluas jangkauan pemasaran produk, agar konsumen dengan mudah mengakses setiap produk yang diperlukan dengan cepat. Dibangunnya sebuah website penjualan online tersebut toko-toko yang masih bersifat konvensional dapat memanfaatkannya sebagai suatu media untuk mempromosikan produk-produk yang dijualnya, agar dapat dikenal lebih luas dan sangat diharapkan untuk dapat mempermudah konsumen untuk tidak datang langsung ke toko untuk membeli barang atau produk [2].

\section{TINJAUAN PUSTAKA}

Cara paling mudah untuk memenuhi persyaratan format penulisan adalah dengan menggunakan dokumen ini sebagai template. Kemudian ketikkan teks anda ke dalamnya

\section{A. Kajian Terdahulu}

Referensi [1], Melakukan penelitian tentang "E-Commerce Web Development in Wiga Art" Wiga Art adalah tempat yang menjual aksesoris yang terbuat dari batu alam yang dihiasi dengan kawan tembaga. Ariyani dkk membangun sebuah web untuk penjualan online produk dari Wiga Art agar meningkatkan layanan pada konsumen, memperluas jangkauan pemasaran dan untuk meningkatkan penjualan produk dengan media yang dapat diakses oleh konsumen.

Referensi [2], Melakukan penelitian tentang "Sistem Informasi Penjualan Online Pada Toko Kreatif Suncom Pacitan" Dalam penelitian itu menghasilkan sebuah website ECommerce yang dapat menjadi media promosi dan memperluas pemasaran toko serta dapat membantu konsumen di daerah pacitan agar lebih dapat mengetahui ketersediaan 
produk yang ada tanpa harus mengunjungi toko kreatif Suncom Pacitan.

Referensi [9], Melakukan penelitian tentang "Pembuatan Electronic Commerce Pada Toko Istana Sragen" dalam penelitiannya dijelaskan bahwa usaha masa kini harus memikirkan kembali strategi pemasaran agar pemasarannya bisa lebih optimal, apalagi dengan perkembangan teknologi sekarang ini maka sudah wajib untuk dapat mengikuti perkembangan jaman pula. Dalam penelitian tersebut Sona membuat suatu sistem informasi pemasaran produk pada Toko Istana Sragen. dengan menggunakan website Electronic Commerce agar dapat mempermudah dalam memasarkan produk. Toko istana merupakan usaha yang bergerak di bidang pemasaran berbagai macam koleksi tas dan aksesoris yang dijualnya.

Referensi [3], Melakukan penelitian tentang "Pengembangan Sistem Informasi Penjualan Alat kesehatan Berbasis Web Pada PT.Alfin Fanca Prima" PT. Alfin Fanca Prima Merupakan salah satu distributor alat kesehatan yang berada di Kalimantan Selatan. PT. Alfin Fanca Prima melayani penjualan alat kesehatan yang berada di Banjarmasin Heldiansyah dkk, menghasilkan sebuah sistem penjualan online berbasis website untuk perusahaan PT.Alfin fanca Prima. Agar konsumen bisa melakukan pembelian secara online tanpa harus mendatangi PT.Alfin Fanca Prima.

Referensi [6], Melakukan penelitian tentang "Pemanfaatan Sistem Informasi Perpustakaan Digital Berbasis Website untuk Para Penulis" penelitian tersebut menghasilkan sebuah website perpustakaan untuk mempermudah bagi para pembaca untuk mendapatkan buku, jurnal digital yang ada dan membantu penulis untuk mempublikasikan hasil karyanya.

Adapun Penelitian di atas yang mendekati dengan penelitian penulis yaitu Referensi [1] yang menghasilkan website penjualan online berbasis website untuk menjual aksesoris yang terbuat dari batu alam. Perbedaan penelitian penulis dengan penelitian di atas adalah dimana penelitianpenelitian di atas membuat sebuah website penjualan online khusus satu tempat toko atau satu perusahaan saja. Sedangkan penulis merancang dan membangun website penjualan online untuk tiga toko offline dalam satu website penjualan online. Penulis juga menambahkan fasilitas chatting pada web untuk memudahkan pelanggan berinteraksi langsung dengan pihak toko. Sedangkan persamaanya adalah dimana penelitian di atas dengan penulis yaitu sama-sama menggunakan bahasa pemograman PHP dan database MySQL.

\section{B. Landasan Teori}

\section{1) Penjualan Online}

Penjualan online adalah melakukan aktivitas penjualan dari mencari calon pembeli sampai menawarkan produk atau barang dengan memanfaatkan jaringan internet yang didukung dengan seperangkat alat elektronik sebagai penghubung dengan jaringan internet [3].

2) $W e b$
World wide web atau sering di kenal sebagai web adalah suatu layanan sajian informasi yang menggunakan konsep hyperlink (tautan), yang memudahakan surfer (sebutan para pemakai komputer yang melakukan browsing atau penelusuran informasi melalui internet). Keistimewaan inilah yang telah menjadikan web sebagai service yang paling cepat pertubuhannya. Web mengijinkan pemberian highlight (penyorotan atau penggaris bawahan) pada kata-kata atau gambar dalam sebuah dokumen untuk menghubungkan atau menunjuk ke media lain seperti dokumen, frase, movie clip, atau file suara. Web dapat menghubungkan dari sembarang tempat dalam sebuah dokumen atau gambar ke sembarang tempat di dokumen lain. Dengan sebuah browser yang memiliki Grapihcal User Interface (GUI), link-link dapat di hubungkan ke tujuannya dengan menunjuk link tersebut dengan mouse dan menekannya. [7].

3) Internet

Definisi internet adalah rangkaian atau jaringan sejumlah komputer yang saling berhubungan. Internet berasal dari kata interconnected-networking. Internet merupakan jaringan global yang menghubungkan suatu jaringan (network) dengan jaringan lainnya di seluruh dunia. Media yang menghubungkan bisa berupa kabel, kanal satelit maupun frekuensi radio. Jaringan internet bekerja bekerja berdasarkan suatu protokol (aturan). TCP/IP yaitu Transmission Control Protocol Internet Protocol adalah protokol standar yang digunakan untuk menghubungkan jaringan-jaringan di dalam internet sehingga data dapat dikirim dari satu komputer ke komputer lainnya. Setiap komputer diberikan suatu nomor unik yang disebut dengan alamat IP [3].

\section{4) PHP My Admin}

PHPMyAdmin adalah perangkat lunak yang bebas ditulis dalam bahasa pemrograman PHP yang digunakan untuk menangani administrasi MYSQL melaui Jejaring jagat Jembar (World Wide Web). PHPMyAdmin mendukung berbagai operasi MySQL, diantaranya (mengolah basis data, tabel-tabel, bidang (fields), relasi (relation), indeks, pengguna (users), perjanjian (permissions), dan lain-lain [9].

\section{5) PHP (Hypertext Preprocessor)}

PHP adalah bahasa pemrograman yang digunakan secara luas untuk penanganan pembuatan dan pengembangan sebuah web dan bias digunakan pada HTML. PHP merupakan singkatan dari "PHP : Hypertext Preprocessor", dan merupakan bahasa yang disertakan dalam dokumen HTML, sekaligus bekerja di sisi server (server-side HTML-embedded scripting). Artinya sintaks dan perintah yang diberikan akan sepenuhnya dijalankan di server tetapi disertakan pada halaman HTML biasa, sehingga script-nya tak tampak disisi client.

PHP dirancangan untuk dapat bekerja sama dengan database server dan dibuat sedemikian rupa sehingga pembuatan dokumen HTML yang dapat mengakses database menjadi begitu mudah. Tujuan dari bahasa scripting ini adalah untuk membuat aplikasi di mana aplikasi tersebut yang dibangun oleh PHP pada umumnya akan memberikan hasil 
pada web browser, tetapi prosesnya secara keseluruhan dijalankan di server [7].

\section{6) $X A M P P$}

XAMPP adalah aplikasi yang berfungsi sebagai server yang berdiri sendiri (localhost), yang terdiri beberapa program antara lain : Apache HTTP Server, MySQL database, dan penerjemah bahasa yang ditulis dengan bahasa pemrograman PHP dan Perl. Nama XAMPP sendiri merupakan singkatan dari X empat sistem operasi, yang meliputi Apache, MySQL, PHP dan Perl. Program ini tersedia dalam GNU (General Public License), merupakan web server yang mudah untuk digunakan yang dapat menampilkan halaman web yang dinamis [6].

7) $C S S$

CSS adalah singkatan dari Cascading Style-Sheet, yaitu sebuah pengembangan atas kode HTML yang sudah ada sebelumnya. Dengan CSS, bisa menentukan sebuah struktur dasar halaman web secara lebih mudah dan cepat, serta irit size [2].

8) Adobe Dreamweaver CS 6

Dreamweaver merupakan software aplikasi yang digunakan sebagai HTML editor professional untuk mendesain web secaara visual. Aplikasi ini juga yang biasa dikenal dengan istilah WYSIWYG (What You See Is What You Get), yang intinya adalah bahwa pengguna tidak harus berurusan dengan tag-tag HTML untuk membuat sebuah situs. Selain itu, Dreamweaver juga memberikan keleluasan kepada kita untuk menggunakannya sebagai media penulisan bahasa pemograman web [3].

\section{9) Model Waterfall}

Model waterfall adalah model yang paling banyak digunakan untuk tahap pengembangan. Model waterfall ini juga dikenal dengan nama model tradisional atau model klasik. Model air terjun (waterfall) sering juga disebut model sekuensial linier (squential linear) atau alur hidup klasik (Classic cycle)". Model air terjun ini menyediakan pendekatan alur hidup perangkat lunak secara sekuensial terurut dimulai dari analisis, desain, pengkodean, pengujian dan tahap pendukung (support) [8]

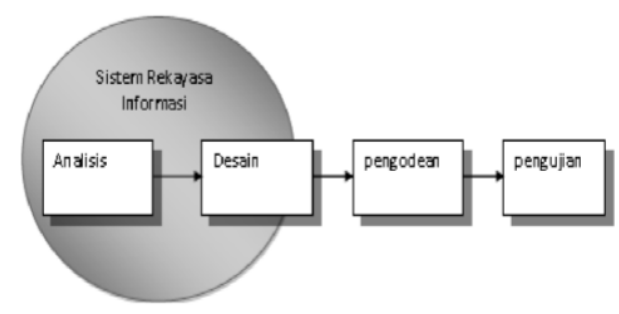

Gbr. 1 Metode Waterfall

(Sumber : Rahmayu, 2016)

10) E-Commerce

E-Commerce merupakan konsep dagang berupa prosedur jual-beli yang terdapat pada internet. E-Commerce adalah suatu konsep yang menjelaskan proses pembelian, penjualan dan pertukaran produk, servis dan informasi melalui jaringan komputer yaitu internet. sebagian perusahaan besar ECommerce menjadi bagian dalam pengembangan, pemasaran, penjualan, pengiriman, pelayanan dan pembayaran para pelanggan dengan dukungan dari jaringan para mitra bisnis di seluruh dunia. Perkembangan E-Commerce di Indonesia berjalan seiring berkembangnya internet sejak pertama kali masuk indonesia di awal tahun 1990-an. Saat ini kegiatan ECommerce di Indonesia merambah berbagai jenis kegiatan bisnis dari skala industri kecil sampai kepada industri yang besar.

Secara umum E-Commerce dapat diklasifikasikan kedalam empat tipe, antara lain yaitu sebagai berikut. (1) B2C (Business to Customer), dalam tipe ini transaksi online berhubungan langsung antara pelaku bisnis dengan pelanggan secara individual, (2) B2B (Business to Business), dalam tipe ini bisnis membuat transaksi online dengan bisnis lainnya, (3) C2C (Consumen to Consumer), transaksi ada antara individu, pribadi atau konsumen dan ditandai oleh lelang online di mana perusahaan menawar apa yang mereka inginkan dari beberapa pemasok , (4) Mobile Commerce (M- Commerce) memerlukan pembelian dan penjualan barang dan jasa melalui jaringan nirkabel seperti perangkat smartphone [13].

Keuntungan e-commerce untuk Perusahaan dapat memperpendek jarak, perluasan pasar, perluasan jaringan mitra usaha serta efisiensi, dengan kata lain dapat mempercepat service ke pelanggan dan Mengurangi biayabiaya yang terkait dengan kertas, seperti cost pos surat, pencetakan, report, dan sebagainya. sehingga bisa menambah pendapatan. Untuk Consumen dapat lebih efisien, aman dengan cara fisik serta flexible. Untuk Orang-orang Umum dapat mengurangi polusi serta pencemaran lingkungan, buka kesempatan kerja baru, beruntung dunia akademis dan menambah mutu SDM. kerugian e-commerce yaitu dapat menambah individualisme, pada perdagangan elektronik seorang bisa bertransaksi serta memperoleh barang/layanan yang dibutuhkan tidak bersua dengan siapa saja. Kadangkadang juga dapat menyebabkan kekecewaan dan terkadang apa yang terlihat di gambar atau yang dipandang dilayar monitor computer tidak sama dengan apa yang di pandang secara kasat mata [5].

Karakteristik e-commerce yaitu sebagai berikut. (1) Transaksi tanpa batas pada pengusaha kecil dan menengah. Pengusaha dapat memasarkan produknya secara internasional cukup dengan membuat sebuah situs web atau dengan memasang iklan-iklan di situs-situs internet tanpa ada batas waktu. tentu saja pelanggan dari seluruh dunia dapat mengakses situs web tersebut dan dapat melakukan transaksi secara online. (2) transaksi anonim yaitu para penjual dan pembeli dalam melakukan sebuah transaksi melalui internet tidak harus saling bertatap muka. (3) Produk digital dan non digital. Produk-produk digital seperti software komputer, musik dan produk lainnya yang bersifat digital dapat dipasarkan melalui internet dengan cara mendownload secara elektronik. (4) 
Produk barang tak terwujud. Banyak perusahaan-perusahaan yang bergerak dibidang e-commerce dengan menawarkan barang yang tidak berwujud seperti data, software dan ide-ide yang dijual melalui internet. Implementasi e-commerce pada dunia industri yang penerapannya semakin lama semakin luas [10].

\section{PERANCANGAN}

\section{A. Data dan Alat Penelitian}

1) Data Penelitian

A. Sumber Data Sumber data yang digunakan dalam penulisan laporan ini adalah data skunder. Data sekunder adalah data penelitian yang berupa tulisan, file atau informasi yang terlihat. Data yang di dapat dari Toko adalah data barang, daftar harga, jenis produk, gambar produk dan lain-lain.

B. Teknik Pengumpulan data.

1) Metode Wawancara

Menanyakan bagaimana proses pengolahan data transaksi dan Menanyakan tentang sistem yang sedang digunakan apakah dalam pengolahan data menggunakan sistem komputerisasi atau masih manual dalam penyimpanan data.

\section{2) Metode Studi Pustaka}

Metode ini dilakukan dengan membaca dan memahami jurnal atau buku-buku literatur yang ada hubungannya dengan penelitian yang digunakan sebagai landasan teori dalam pemecahan masalah agar penulisan dan penelitian tidak menyimpang dari teori.

2) Alat yang digunakan

\section{A. Software}

1) XAMPP Program ini mempunyai satu paket web server Apache, PHP dan MySQL.

2) Dreamweaver CS6 sebagai teks editor untuk desain dan penulisan script PHP.

3) Web Browser yang digunakan Mozila Firefox, yang berguna untuk menampilkan interface program yang telah dibuat.

$B$. Hardware yang digunakan dalam pembuatan program ini.

1) Processor Intel Pentium $2,10 \mathrm{GHz}$

2) RAM $3.00 \mathrm{~GB}$

3) Hardisk $500 \mathrm{~GB}$

4) Mouse Logitech

\section{B. Perancangan Sistem}

1) Sistem penjualan yang sedang berjalan dilihat pada Gbr.2.

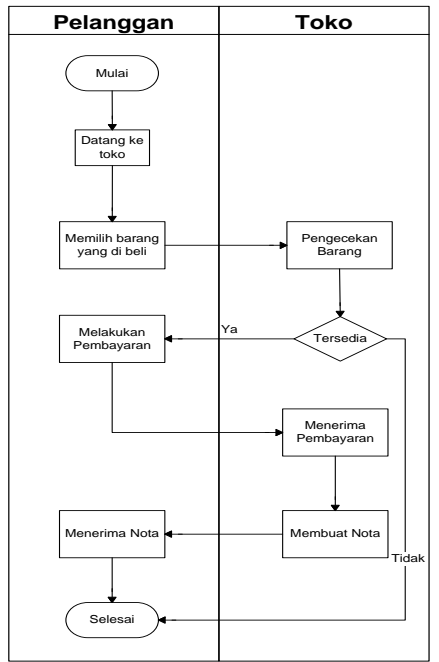

Gbr. 2 Sistem penjualan yang sedang berjalan

2) Sistem penjualan yang diusulkan dapat di lihat pada Gbr.3.

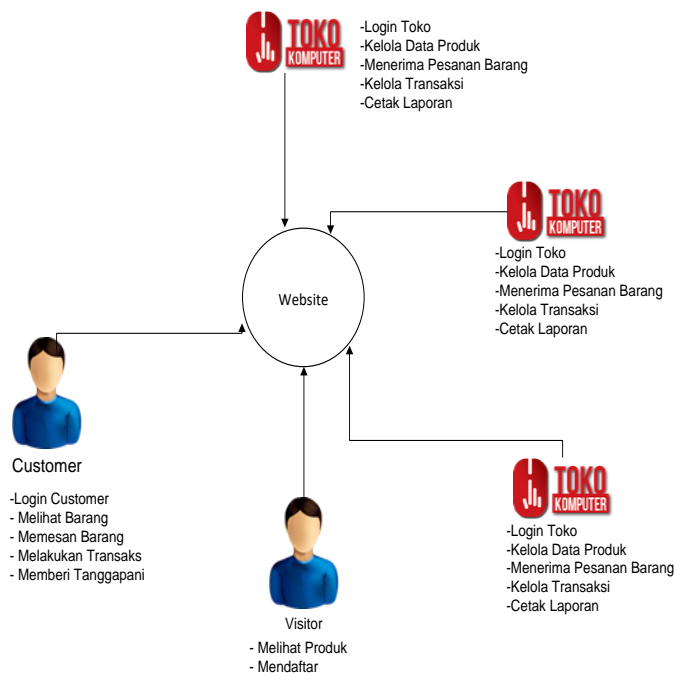

Gbr. 3 Sistem penjualan yang di usulkan

3) Use Case Diagram dilihat pada Gbr.4. 


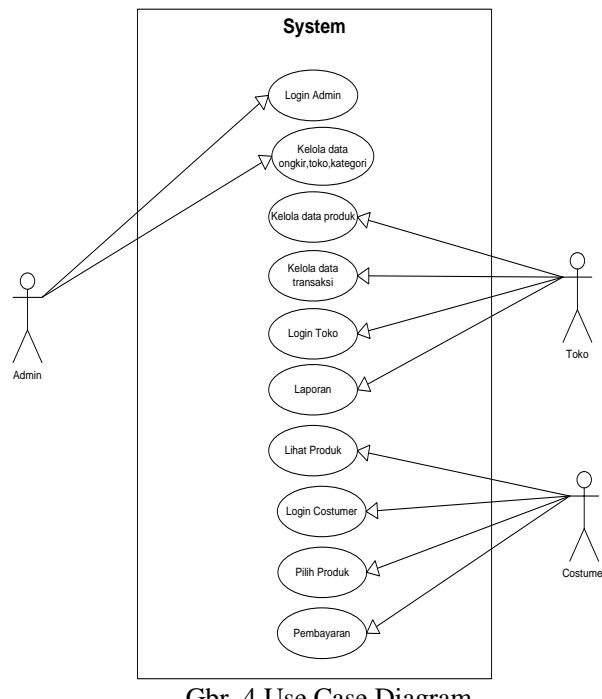

Gbr. 4 Use Case Diagram

4) Perancangan Metode Waterfall.

Berikut merupakan cakupan aktifitas menggunakan pendekatan Model Waterfall:

\section{1) Analisis}

Peneliti mengumpulkan informasi dengan teknik wawancara mengenai sistem yang sudah ada untuk di analisa. Dengan menganalisa sistem yang sudah ada peneliti dapat mengetahui permasalahan-permasalahan yang terdapat di sistem tersebut. Permalahan-permalahan yang terdapat di sistem yang sudah ada yakni dimana Sistem pemasaran produk toko masih menggunakan brosur, untuk melakukan transaksi pembelian produk antara pembeli dengan penjual harus saling bertatap muka, pihak toko melakukan promosi produk dengan membuka stand di depan toko dan pembuatan laporan penjualan dan produk di toko masih manual.

\section{2) Desain}

Peneliti merancang antarmuka program menggunakan aplikasi Sublime Text sebagai text editor dengan menggunakan bahasa pemograman php. Peneliti merancang tampilan homepage admin master, tampilan kelola data toko admin master, tampilan kelola transaksi pembelian admin master, tampilan ongkos kirim admin master, tampilan kelola data produk admin toko, tampilan chatting admin toko, tampilan dasboard admin toko, tampilan laporan produk admin toko, tampilan laporan penjualan admin toko, tampilan homepage customer, tampilan kelola transaksi customer, tampilan keranjang belanja customer dan tampilan awal pelanggan.

\section{3) Pembuatan Kode}

Peneliti menggunakan bahasa pemograman php dan html untuk menterjemahkan perancangan kedalam bentuk bahasa yang dimengerti komputer. Pembuatan kode di halaman antar muka pengunjung untuk menampilkan barang dari toko, pendaftaran pengunjung sebagai pelanggan, form login pelanggan. kemudian Pembuatan kode di halaman antar muka pelanggan untuk menampilkan produk yang di jual toko, melakukan transaksi pembelian produk. kemudian Pembuatan kode di halaman antar muka admin toko untuk mengelola produk, mengelola pesanan, mengelola transaksi dan mengelola laporan.

\section{4) Pengujian sistem}

Peneliti melakukan pengujian aplikasi dengan menggunakan google chrome dan apache sebagai servernya. Peneliti melakukan pengujian halaman antar muka pengunjung, halaman antar muka pelanggan, halaman transaksi pelanggan, halaman antar muka admin toko, halaman pesanan barang admin toko, halaman transaksi admin toko, cetak laporan penjualan dan laporan produk. Dengan melakukan pengujian peneliti dapat menemukan kesalahankesalahan yang mungkin terjadi sehingga peneliti dapat melakukan perbaikan dan juga peneliti dapat memastikan bahwa hasil yang di terapkan telah tercapai.

5) Relationship Diagram ( ERD)

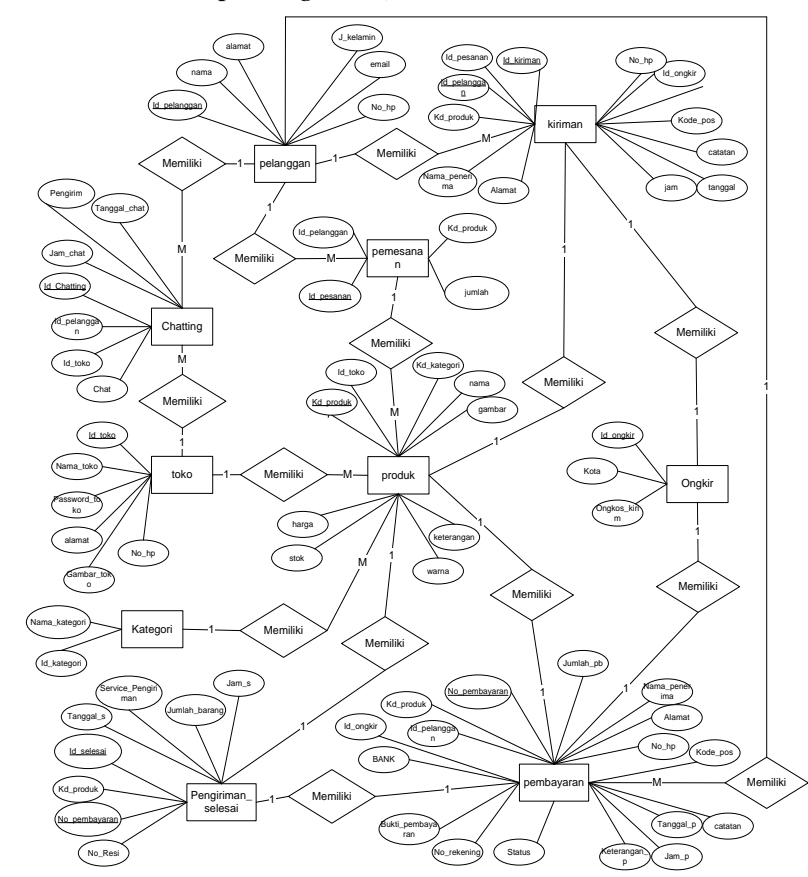

Gbr. 5 Entity Relationship Diagram (ERD)

6) Perancangan Antar Muka.

1) Tampilan Form Input data Barang. 


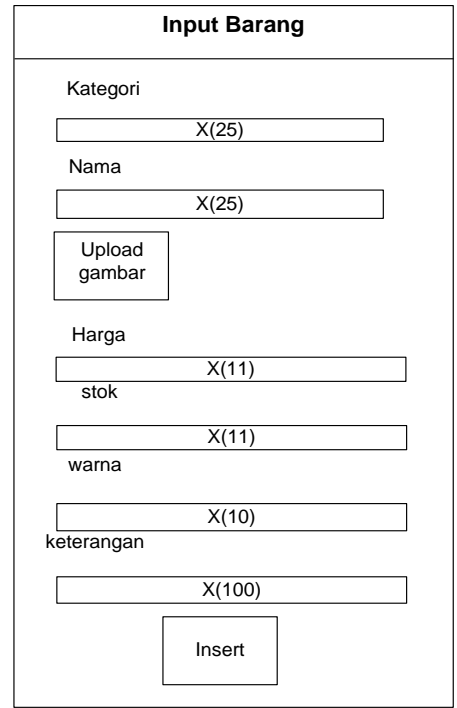

Gbr. 6 Form Input Data Barang

2) Form Input Pembatalan Pembelian.

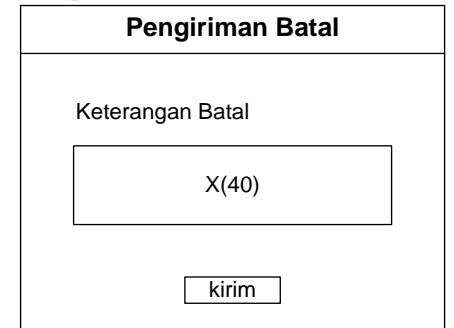

Gbr. 7 Form Input Pembatalan Pembelian

3) Form Input Chatting.

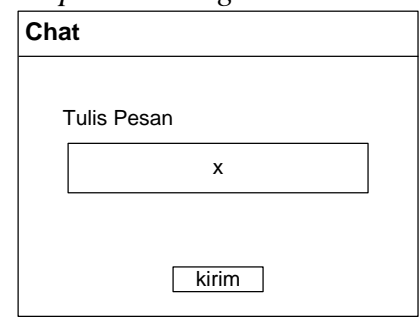

Gbr. 8 Form Input Chatting

4) Form Input Kiriman.

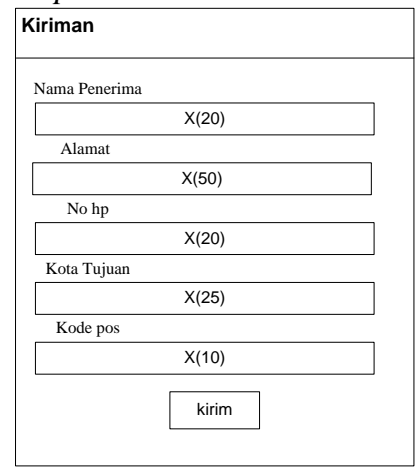

Gbr. 9 Form Input Chatting

5) Form Input Pembayaran.

6)

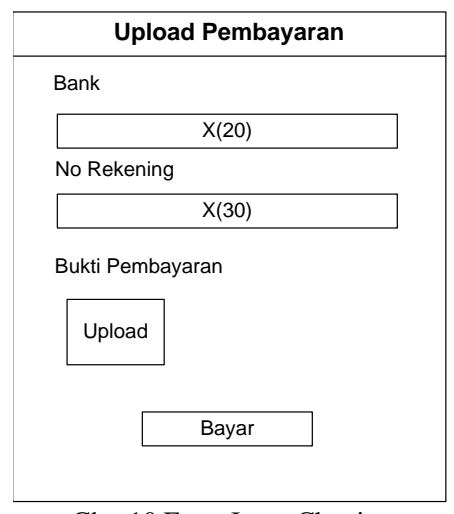

Gbr. 10 Form Input Chatting

7) Form Input Daftar Pelanggan.

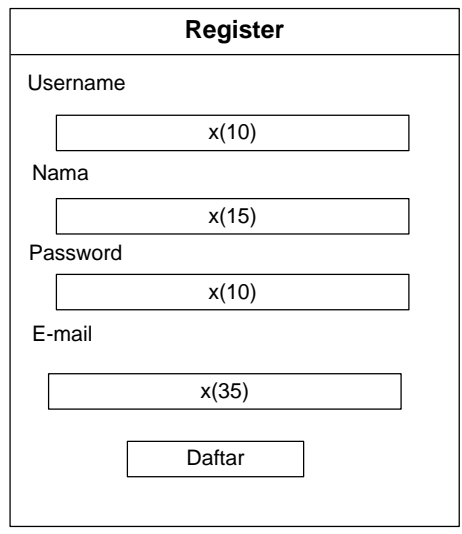

Gbr. 11 Form Input Daftar Pelanggan

\section{IV.HASIL DAN PENGUJIAN}

\section{A. Hasil}

Pada penelitian ini menghasilkan sebuah website Toko Online. Website toko online ini berfungsi untuk memberikan kemudahan kepada pelanggan agar dapat mengetahui informasi produk atau barang yang dijual oleh toko dengan cepat. Terdapat bagian admin toko yang dapat menginput produk, melihat produk, menghapus produk, mengedit produk, mengelola data transaksi, mencetak laporan penjualan dan admin toko dapat membatalkan pesanan barang dari pelanggan. Admin master dapat mengelola data toko, data kategori produk, data ongkir dan dapat melihat barang yang sudah terjual. Website Toko Online ini terdapat juga fasilitas chatting antara pelanggan dan toko agar pelanggan dan toko mudah untuk saling berintraksi. 
Halaman Home untuk pelanggan terdapat Menu transaksi untuk melihat transaksi pembelian produk, kemudian pada halaman ini terdapat juga menu laptop, komputer dan aksesoris yang digunakan untuk melihat kategori produk yang terdiri dari laptop, komputer dan aksesoris secara detail. Terdapat nama Produk, Gambar dan Harga per satuan. Untuk pelanggan yang membeli produk, klick gambar untuk melihat detail produk kemudian klick beli.

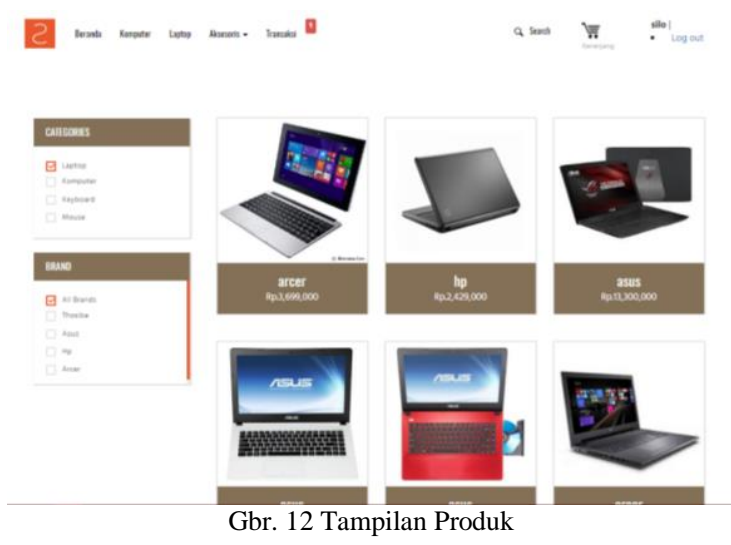

Di tampilan home pelanggan terdapat gambar keranjang belanja untuk melihat Produk yang ada di keranjang belanja Terdapat tombol lanjut beli dan tombol delete untuk mengahapus produk dari keranjang belanja.

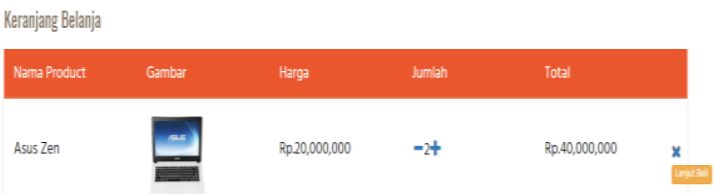

Gbr. 13 Tampilan Keranjang Belanja

Menu daftar produk untuk melihat daftar produk yang dijual toko. Setiap data terdapat aksi edit untuk mengedit data produk dan hapus untuk menghapus produk, dan juga terdapat aksi tambah produk untuk admin toko yang akan menambah data produk kedalam website.

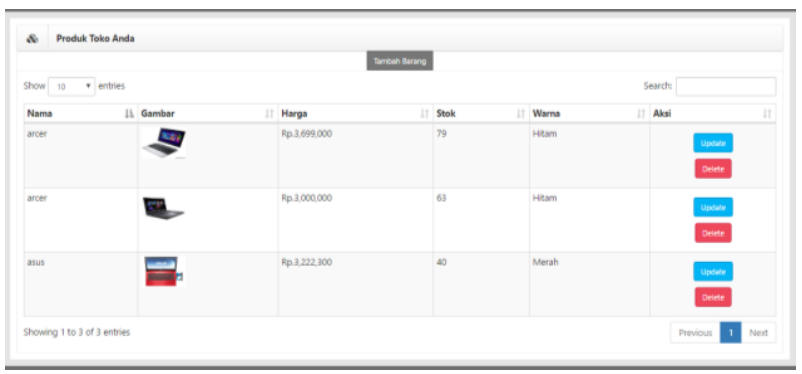

Gbr. 14 Tampilan Daftar Produk
Menu data pesanan untuk melihat smua pesanan produk yang dilakukan oleh pelanggan.

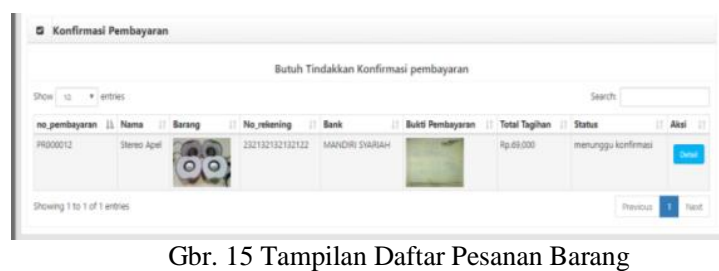

Menu transaksi konfirmasi untuk melihat pembayaran pelanggan yang sudah di cek dan di konfirmasi oleh admin toko.

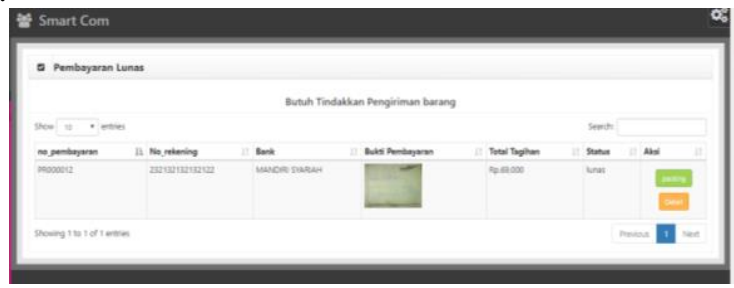

Gbr. 16 Daftar Pembayaran Lunas

Menu Transaksi barang yang sudah di terima pelanggan untuk melihat barang yang di konfirmasi pelanggan bahwa barang sudah diterima oleh pembeli.

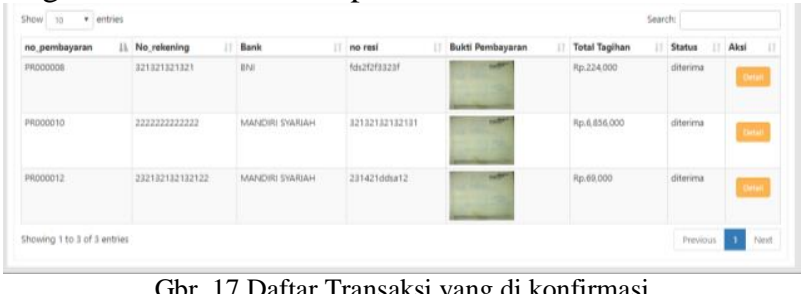

Menu Transaksi batal untuk melihat produk yang dibatalkan oleh admin toko di sebabkan oleh suatu kendala.

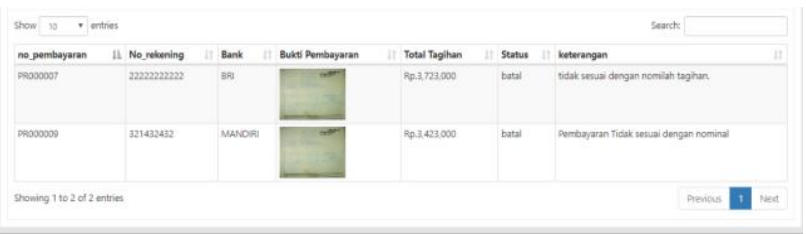

Gbr. 18 Daftar Transaksi yang di batalkan

Daftar Tagihan pelanggan. Apabila tidak di bayar dalam jangka waktu 3 hari maka tagihan dan pemesanan barang akan terhapus otomatis dan pelanggan harus memesan kembali barang.

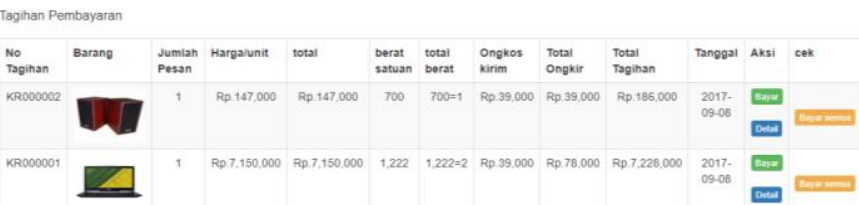

Gbr. 19 Daftar Tagihan Pembayaran 


\section{B. Pengujian}

Setelah dilakukan pengujian sistem, maka didapatkan hasil pengujian seperti yang terdapat pada tabel 1 .

TABEL I

PENGUJIAN PADA WEB BROWSER

\begin{tabular}{|c|c|c|l|l|}
\hline No & $\begin{array}{c}\text { Browse } \\
\mathbf{r}\end{array}$ & Versi & Hasil & \multicolumn{1}{|c|}{ Keterangan } \\
\hline 1 & $\begin{array}{l}\text { Google } \\
\text { chrome }\end{array}$ & 60.0 .3112 .90 & $\begin{array}{l}\text { Berhasi } \\
1\end{array}$ & $\begin{array}{l}\text { Aplikasi dapat } \\
\text { dijalankan sesuai } \\
\text { dengan yang di } \\
\text { harapkan }\end{array}$ \\
\hline 2 & $\begin{array}{l}\text { Mozila } \\
\text { firefox }\end{array}$ & 3.5 .2 & Berhasi & $\begin{array}{l}\text { Aplikasi dapat } \\
\text { dijalankan sesuai } \\
\text { dengan yang di } \\
\text { harapkan }\end{array}$ \\
\hline
\end{tabular}

\section{PENUTUP}

Berdasarkan yang dilakukan peneliti. Maka dapat diambil suatu kesimpulan bahwa aplikasi toko online berbasis web dijalankan menggunakan Google chrome dan Mozila Firefox berhasil dijalankan dengan baik. Stok barang dari toko di database akan otomatis berkurang jika pelanggan telah melakukan pembelian barang kemudian Tagihan pembayaran pelanggan otomatis terhapus apabila dalam 3 hari pelanggan tidak melakukan pembayaran. Toko online berbasis web ini digunakan untuk mempermudah pelanggan dalam berbelanja, bertransaksi, berkonsultasi dengan pihak toko, mempermudah pelanggan untuk melihat produk secara detail, kapan saja, dimana saja serta mempermudah pelanggan melakukan pemesanan tanpa harus datang ke lokasi toko. Dan mempermudah pihak toko untuk membuat laporan data produk, melakukan promosi produk toko dan laporan penjualan.

Untuk penelitian selanjutnya Website Toko Online dapat dilakukan pengembangan dan perbaikan dengan menambahkan grafik untuk dapat mengetahui tingkatan pemesannan produk perbulan, membuat statistik pengunjung dan adanya pengembangan di fasilitas chatting agar dapat mengirim file dan gambar

\section{TERIMA KASIH}

Terima kasih terutama kepada kedua orang tua saya yang sudah merawat dan membesarkan saya. Kemudian terimakasih kepada dosen-dosen Teknik informatika Politeknik negeri bengkalis dan terimakasih kepada temanteman seperjuangan.

\section{REFERENSI}

[1] Ariyani, W.,Hanantjo, D., dan Purnama, E.K., 2015, E-Commerce web Development in Wiga Art, International Journal of Science and Research,(4) 5, 2319-7064.

[2] Hasanah, U., 2013, Sistem Informasi Penjualan Online pada toko kreatif Suncom Pacitan, Indonesian Journal on Networking and Security, (2) 4, 2302-5700.

[3] Heldiansyah., Indera, R., AO, P.A., dan Shadiq, F., 2015 , Pengembangan Sistem Informasi Penjualan Alat Kesehatan Berbasis Web Pada PT.Alfin Fanca Prima, Jurnal POSITIF, 37 - 45.

[4] Indah, N.I., 2013 Pembuatan Sistem Informasi Penjualan Pada Toko Sehat Jaya Elektronik Pacitan, Indonesian Jurnal on Computer Science - Speed, (10) 2, 1979 - 9330.

[5] Indriati, R., 2015, "Pengertian E-Commerce", Website http://www.gubuginformasi.com/2014/02/pengertian-ecommerce.html, diakses tanggal 31 Februari 2017.

[6] Jamil, M., dan Bunyamin., 2015, Pengembangan Aplikasi Sistem Informasi Laporan Keuangan Walisantri Di Pondok Pesantren AlHalim Garut, Jurnal Algoritma Sekolah Tinggi Teknologi Garut, (12) 1, 2302-7339.

[7] Palit, R., Rindengan, Y., Lumenta, A., 2015, Rancang Sistem Informasi Keuangan Gereja Berbasis Web Di Jemaat GMIM Bukit Moria Malalayang, E-Journal Teknik Elektro dan Komputer, (4) 7, 2301-8402.

[8] Prayitno, A., dan Safitri, Y., 2015, Pemanfaatan Sistem Informasi Perpustakaan Digital Berbasis Website Untuk Para Penulis , Indonesian Journal on Software Engineering, (1) 1, 2461 - 0690

[9] Rozaq, A., Lestari, F.K., dan Handayani, S., 2015, Sistem Informas Produk Dan Data Calon Jamaah Haji Umroh Pada PT_Travellindo Lusiyana Banjarmasin Berbasis Wen, Jurnal POSITIF, 1-13.

[10] Rahmayu, M., 2016 Rancang Bangun Sistem Informasi Pada rumah Sakit Dengan Layanan Intranet Menggunakan Metode Waterfall, Jurnal Evolusi, (4) 2, 2338 - 8161

[11] Sona, P.A.V., 2013 Pembuatan Electronic Commerce Pada toko Istana Sragen, Seminar Riset Unggulan Nasional Informatika dan Komputer FTI UNSA, (2) 1, 2302-1136.

[12] Wanwan, E., 2015, "Pengertian E-Commerce", Website http://www.ekowiner.web.id/2015/04/pengertian-e-commerceperniagaan-elektronik.html, diakses tanggal 31 Februari 2017.

[13] Kurnia, R., dan Priambodo, B., 2015, Pengaruh Sosial Media Terhadap Bisnis E-Commerce Di Indonesia, Jurnal Ilmiah E-Commerce Sistem Informasi, 8-29. 